\title{
Interdisciplinary mathematical methods for societal decision-making and resilience
}

\author{
Zachary A. Collier ${ }^{1}$. James H. Lambert ${ }^{2} \cdot$ Igor Linkov $^{3}$
}

Published online: 29 February 2020

○) Springer Science+Business Media, LLC, part of Springer Nature 2020

This issue marks the beginning of the eighth year of Environment Systems \& Decision's publication. In this issue, we feature research articles at the intersection of society and analytics. Several interdisciplinary articles explore how modeling approaches, leveraging expert and stakeholder inputs, can be used for decision-making and policy development in complex environmental and economic systems. Topics such as greenhouse gas emissions, ecosystem services, water quality, and environmental restoration are discussed in this issue. Rather than make ad hoc decisions, formalized and structured decision-making results in better decisionmaking, especially with respect to complex systems involving people, technology, and the environment.

First, Cooke and Golub (2020) described a market-based mechanism to monetize uncertainty reduction. Using models for pricing commodity futures, they found that a reduction in weather-related uncertainty can yield billions of dollars in consumer surplus. Yao et al. (2020) conducted a content analysis on news media and government reports related to environmental policy-making. Their results explored the relationships between public opinion, presidential agendas, and media coverage on environmental policy. Walpole et al. (2020) explored the role of home attachment in the decisionmaking process of whether or not to evacuate during a wildfire. The authors tested the effect of different informational cues on evacuation decisions, finding a complex relationship between attachment, information, and evacuation. McKay

Zachary A. Collier

zachary@collierresearchsystems.com

James H. Lambert

lambert@virginia.edu

Igor Linkov

igor.linkov@usace.army.mil

1 Collier Research Systems, Barboursville, VA, USA

2 University of Virginia, Charlottesville, VA, USA

3 US Army Engineer Research \& Development Center, Concord, MA, USA et al. (2020) evaluated the effectiveness of socio-ecological system governance of an environmental cleanup and redevelopment project. The authors created a quality governance framework and diagnostic capacity tool to provide insights into how governance can be improved. Höfer et al. (2020) developed a Bayesian network model for tangible and intangible ecosystem services. Using Curonian Lagoon in Lithuania as a case study, the authors demonstrated how expert uncertainty can be incorporated into their methodological framework. van der Merwe et al. (2020) linked concepts of resilience of critical infrastructure services with individual sense-making and sense of meaning. They found that by understanding how individuals make sense of the world, societies can build more resilient infrastructure systems. Yoshioka and Yaegashi (2020) developed a mathematical model for controlling the growth rate of harmful algal blooms. The model was demonstrated in the case of a river downstream of a dam. Cary (2020) modeled greenhouse gas emissions from sub-sectors of the US energy sector relative to gross domestic product in an econometric model. The model was used to forecast emissions for the energy sector. Koengkan et al. (2020) created a model to assess the impacts of globalization on $\mathrm{CO}_{2}$ emissions in Latin American and Caribbean nations. The author explored dimensions of globalization, including economic, social, and political factors, and how they affect emissions, with associated implications for policy. Nautiyal et al. (2020) compared conservation practices between two bird sanctuaries. They found that despite having different approaches to conservation, both sanctuaries effectively protected the threatened bird species.

The Editorial Board met in December during the Society for Risk Analysis Annual Meeting to discuss the strategic vision for the journal. We are happy to welcome four new members to the Editorial Board who bring a wealth of expertise across a number of relevant disciplines: Hiba Baroud (Vanderbilt University), Doug Bessette (Michigan State University), Gilberto Montibeller (Loughborough University), and Giovanni Sansavini (ETH Zurich). 


\section{References}

Cary M (2020) Have greenhouse gas emissions from US energy production peaked? State level evidence from six subsectors. Environ Syst Decis. https://doi.org/10.1007/s10669-019-09754-y

Cooke R, Golub A (2020) Market-based methods for monetizing uncertainty reduction. Environ Syst Decis. https://doi.org/10.1007/ s10669-019-09748-w

Höfer S, Ziemba A, El Serafy G (2020) A Bayesian approach to ecosystem service trade-off analysis utilizing expert knowledge. Environ Syst Decis. https://doi.org/10.1007/s10669-019-09742-2

Koengkan M, Fuinhas JA, Santiago R (2020) Asymmetric impacts of globalisation on $\mathrm{CO} 2$ emissions of countries in Latin America and the Caribbean. Environ Syst Decis. https://doi.org/10.1007/ s10669-019-09752-0

McKay PM, Olabisi LS, Vogt CA (2020) Assessing improvements in socio-ecological system governance using mixed methods and the quality governance framework and its diagnostic capacity tool. Environ Syst Decis. https://doi.org/10.1007/s10669-019-09744-0
Nautiyal S, Kaechele H, Babu MSU, Khan YDI, Dutta H (2020) Avian conservation under two management regimes: a case study from the viewpoint of governance and social dimension. Environ Syst Decis. https://doi.org/10.1007/s10669-019-09745-z

van der Merwe SE, Biggs R, Preiser R (2020) Sensemaking as an approach for resilience assessment in an Essential Service Organization. Environ Syst Decis. https://doi.org/10.1007/s10669-01909743-1

Walpole HD, Wilson RS, McCaffrey SM (2020) If you love it, let it go: the role of home attachment in wildfire evacuation decisions. Environ Syst Decis. https://doi.org/10.1007/s10669-019-09741-3

Yao Q, Liu Z, Stephens LF (2020) Exploring the dynamics in the environmental discourse: the longitudinal interaction among public opinion, presidential opinion, media coverage, policymaking in 3 decades and an integrated model of media effects. Environ Syst Decis. https://doi.org/10.1007/s10669-019-09746-y

Yoshioka H, Yaegashi Y (2020) A growth rate control problem of harmful species population and its application to algae bloom. Environ Syst Decis. https://doi.org/10.1007/s10669-019-09736-0 